\title{
Developmental Assets and Healthy Lifestyles among Spanish Youth
}

\author{
Diego Gomez-Baya', Carmen Martin-Gomez', Cátia Branquinho², Gina Tomé2, \\ Margarida Gaspar de Matos ${ }^{2}$ \\ 1 Department of Social, Developmental and Educational Psychology, Universidad de Huelva, Spain \\ 2 Faculty of Human Kinetics, Universidade de Lisboa, Portugal
}

\section{Abstract}

Developmental assets may be defined as the internal and external resources within an individual's social ecology that predict positive outcomes. The present work aimed to examine the relationship between developmental assets and healthy lifestyles among Spanish youth. Data from the PYD Cross-national Project in Spain were collected through an anonymous questionnaire based on The Developmental Assets Profile and certain lifestyle indicators. The sample comprised 768 youth $\left(M_{\text {age }}=19.50, S D=2.27\right.$; $60.5 \%$ female). Youth who reported having been drunk or having smoked in the last 30 days, and those who indicated they had inhaled a substance or consumed marijuana or another illicit drug over the previous 12 months were shown to have less of a commitment to learning, lower positive values, and fewer social skills. Further, participants who reported physical activity (at least $30 \mathrm{~min}$ ) two or more times per week revealed greater empowerment, the constructive use of time, positive values, and a positive identity. Moreover, the consumption of at least one serving of fruit or vegetables every day was associated with more positive values. Gambling was related to lower scores for commitment to learning, social competencies, positive values, boundaries and expectations, and social support. The results suggest the need to design programmes to foster developmental assets and promote healthy lifestyles among young people.

Keywords: developmental assets, lifestyles, youth, Spain, cross-sectional 


\section{Razvojni viri in zdrav življenjski slog med mladimi v Španiji}

\section{Povzetek}

Razvojne vire lahko opredelimo kot notranje in zunanje moči znotraj posameznikovega socialnega okolja, ki napovedujejo pozitivne razvojne izide. Namen raziskave je bil preučiti odnos med razvojnimi viri in zdravim življenjskim slogom španskih mladostnikov. Uporabljeni so bili podatki iz projekta PYD v Španiji, zbrani z uporabo anonimnega vprašalnika, ki temelji na Profilu razvojnih virov (The Developmental Assets Profile) in nekaterih kazalnikih življenjskega sloga. V raziskavi je sodelovalo 768 mla$\operatorname{dih}\left(M_{\text {starost }}=19,50, \mathrm{SD}=2,27 ; 60,5 \%\right.$ žensk $)$. Mladi, ki so v zadnjih 30 dneh poročali o pijanosti ali kajenju, in tisti, ki so v zadnjih 12 mesecih navajali vdihavanje snovi, uživanje marihuane ali drugih prepovedanih drog, so pokazali nižjo predanost učenju, nižje pozitivne vrednote in nižje socialne kompetence. Poleg tega so udeleženci, ki so dva ali večkrat na teden poročali o telesni aktivnosti (vsaj 30 minut), poročali o višji opolnomočenosti, konstruktivni izrabi časa, pozitivnih vrednotah in pozitivni identiteti. Poleg tega je bilo uživanje vsaj ene enote sadja ali zelenjave vsak dan povezano z bolj pozitivnimi vrednostmi. Stave so bile povezane z nižjo stopnjo predanosti učenju, nižjimi socialnimi kompetencami, nižjimi pozitivnimi vrednotami, pričakovanji in mejami ter nižjo socialno podporo. Rezultati kažejo, da je programe za krepitev razvojnih virov smiselno oblikovati vzporedno s promocijo zdravega načina življenja v obdobju mladostništva. Ključne besede: razvojni viri; življenjski slogi; mladina, Španija; prečna študija.

Youth and adolescent psychology has chiefly focused on the study of emotional problems and risk behaviours, even though the transition to adulthood is better characterised as a process of growth and increasing one's competencies (Larson, 2000). Research on youth samples has thus traditionally taken a deficit-based approach, with its research findings marking interventions and policies based on coercive methods instead of the development of strengths (Geldhof et al., 2014). In the last few years, more research has studied the positive indicators of young people's adjustment to adulthood (Lippman et al., 2011). Because to date interventions that only addressed risks and vulnerabilities have shown a smaller impact, the promotion of young people's healthy development needs a strengths-based approach (Benson et al., 2006; Catalano et al., 2002; Kia-Keating et al., 2011). 
In this vein, the Positive Youth Development (PYD) theory is a strengths-based approach to the developmental transition of young individuals to adulthood that argues the development of health and well-being is the outcome of the alignment of their internal strengths and contextual assets (Lerner et al., 2005; Lerner et al., 2003; Lerner et al., 2015). Derived from developmental systems theory, PYD considers the mutually beneficial interactions between the individual and the context to be adaptive regulations. Developmental Assets (DAs) theory was postulated within this relational, developmental systems meta-model to describe the individual and the contextual resources which may foster PYD (Scales, 2011; Lerner et al., 2015). DAs theory integrates the evidence-based resources that: a) relate to fewer risk behaviours (e.g. substance use or violent behaviour) and promote thriving and resilience; b) can be generalised across different social locations; c) foster a balance of the factors on both the ecological and individual levels; d) are available within the capacity of communities to promote their satisfaction; and e) young people are able to easily reach them (Benson et al., 2006; Benson et al., 2011). Two types of DAs exist: internal and external assets (Benson et al., 2011). External assets encompass support, empowerment, boundaries and expectations, and constructive use of time. Internal assets entail four categories: commitment to learning, positive values, social skills, and a positive identity. These internal and external assets are expected to be positively associated (Theokas et al., 2005) and consistent with the relational, developmental systems proposed by Lerner et al. (2011) to integrate individual-context interactions. These assets are cumulative for promoting PYD and for reducing risk behaviours, and can be developed by youth programmes and interventions in their developmental contexts (Benson et al., 2011).

Some studies examined the relationships between developmental assets, risk behaviours and indicators of thriving. Most research has been conducted in the USA. In a survey involving 6,00o adolescents from the USA, Scales et al. (2000) showed that developmental assets explained around half of the variance in a composite index comprising indicators of thriving, including school success, leadership, helping others, maintaining good health, delayed of gratification, valuing diversity and overcoming adversity. In other work, Leffert et al. (1998) concluded that risk behaviours (i.e. alcohol, tobacco, illicit drugs, risky sexual intercourse, depression, suicide, antisocial behaviour, violence, school problems, driving after consuming alcohol, and gambling), were related to less presence of developmental assets. 
Scales (1999) reported a cumulative effect, such that a greater number of assets was associated with fewer risk behaviours and more indicators of thriving. Atkins and colleagues (2002) showed the protective effect of certain developmental assets on adolescent tobacco use in the USA, for example, future aspirations, responsible choices or use of time in organised groups or religion. Bleck and DeBate (2016) provided longitudinal evidence for associations between developmental assets and health behaviours in adolescents and youth from the USA. Direct associations were observed between developmental assets, substance use and physical activity. Further, French et al. (2001) showed that a positive identity is a developmental asset that is considerably strongly and negatively interrelated to binge/purge and weight-loss behaviours. Fulkerson et al. (2006) stated that developmental assets are positively associated with good eating habits (like family dinners) and negatively with high-risk behaviours. Schwartz et al. (2013) showed that community developmental asset was associated with more prosocial behaviours through its positive influence on having a mentor. Moreover, Galinsky and Sonenstein (2011) related developmental assets with greater sexual enjoyment among emerging adults. Valois and colleagues (2009) revealed that developmental assets are positively associated with life satisfaction in adolescents from the USA.

An international study using adolescent and youth samples from the USA, Japan, Lebanon, Albania, Bangladesh and the Philippines concluded that developmental assets could be adapted and used to study positive development in cultural settings other than the USA (Scales, 2011). This conclusion was recently supported by Soares et al. (2019) in a sample of Portuguese adolescents, highlighting the role of overall self-esteem, family support, planning and decision-making, and sense of purpose. In Spain, Gomez-Baya et al. (2021) showed a positive association between internal and external assets with the ${ }_{5} \mathrm{Cs}$ of positive youth development. In Canada, Filbert and Flynn (2010) presented how young people's possession of more developmental assets was associated with more resilience, assessed by more prosocial behaviour, greater self-esteem, better educational performance, and fewer behavioural difficulties in a sample of First Nations young people in care. Kozina and Pivec (2020) studied cross-sectional relationships between developmental assets and bullying among students in Slovenia. They found that less empowerment predicted social bullying, while less constructive use of time was related to verbal victimisation. Less empowerment and less constructive use of time were also predictors of social victimisation. In Norway, Sahar et al. (2020) concluded that two internal assets 
(i.e., positive values and social competence) and two external assets (i.e., support and boundaries and expectations) predicted a risk behaviour (e.g. drunkenness, violence and delinquency) in young people.

In Spain, National Health Survey data (INE, 2017) indicated that people aged $15-24$ spent $66.28 \%$ of their time sitting down, while just $7.23 \%$ spent time walking and $1.58 \%$ performing activities requiring aerobic effort. Only $46.30 \%$ reported moderate to vigorous physical activity in leisure time. Concerning eating habits, $50.76 \%$ of young people aged $15-24$ indicated daily consumption of fruit and $32.53 \%$ daily consumption of vegetables. With regard to substances, $47.86 \%$ had drunk alcohol in the last 2 weeks while $20.66 \%$ had smoked tobacco. The EDADES (2019) survey on alcohol and drugs in Spain revealed that $20.4 \%$ of the population aged $15-$ 24 had consumed cannabis in the previous 12 months. Further, INJUVE (2019) showed that $18.3 \%$ of the sample aged $18-24$ reporting problematic gambling.

The developmental assets' approach is based on the internal and external nutriments that constitute the basis for healthy development (Oliva, 2015). The provision of these assets in the transition to adulthood will encourage young people to follow a healthy lifestyle, which in turn will help them thrive. To our knowledge, no study to date using a sample of Spanish youth has examined how developmental assets may be the nutriments for a healthy lifestyle. Moreover, greater research is needed to determine whether a universal pattern of relationship exists between developmental assets and healthy behaviour, an issue not clearly addressed by recent literature. The aim of this research was to examine the association between developmental assets and different behaviours in youth lifestyles, such as the level of practice of physical activity, the consumption of fruit and vegetables, the consumption of alcohol and tobacco, the use of illegal drugs (i.e., marijuana, substance inhalation or others) and gambling. Building on previous research into thriving and developmental assets, we hypothesised that a healthy lifestyle (composed of the presence of particular protective behaviours and the lack of certain risky behaviours) was associated with higher scores for developmental assets, while unhealthy lifestyles were related to lower scores for such assets. Internal assets may provide a platform for facilitating the choice of protective behaviours, instead of risky ones, which may foster healthier personal development. External assets may also facilitate the availability and reinforcement of protective behaviours of health and well-being in adolescents and youth. Thus, developmental assets may 
be the substrate which feeds the development of lifestyles that foster health and well-being.

\section{Methods}

\section{Participants}

The sample comprised 768 youth (60.5\% female), aged between 17 and 29 $\left(M_{\text {age }}=19.50, S D=2.27\right)$, and enrolled in seven institutes for upper secondary education $\left(61.9 \%, M_{\text {age }}=18.81, S D=2.20\right)$ and three universities $(38.1 \%$, $M_{\text {age }}=20.63, S D=1.90$ ), in the region of Andalusia in southern Spain. Most participants were Spanish (95.8\%), with most living with both parents, one parent, or other adults (90.4\%). A convenient sampling procedure was followed to reach a heterogenous sample, with schools of different ownership (40\% public, 60\% private) and different habitats (40\% rural, 60\% urban). Concerning the level of studies, $43.1 \%$ of the sample were in their first or second year of a baccalaureate programme, $18.8 \%$ were enrolled in their first or second year of vocational training, whereas $38.1 \%$ were in their first two years of a university degree. In each educational centre, the participating classes were randomly selected.

\section{Instrument and variables}

The questionnaire included a scale on DAs and items for assessing lifestyles:

Developmental Assets. We used the Developmental Assets Profile validated by the Search Institute (Scales, 2011), after a back-translation from English to Spanish by native speakers with expertise in psychology. This questionnaire is composed of 58 items, distributed in 8 related subscales, 4 internal assets and 4 external assets. The dimensions of external assets were: support ( 7 items; e.g. "I have a family that gives me love and support"), empowerment (6 items; e.g. "I am given useful roles and responsibilities"), boundaries and expectations (9 items; e.g. "I have parents who urge me to do well at school/university") and constructive use of time (4 items; e.g. "I am involved in creative things such as music, theatre or other arts". Some statements were adapted to the academic level, depending on enrolment in university or high school. The dimensions of internal assets were: commitment to learning ( 7 items, e.g. "I am trying to learn new things"), positive values (11 items; e.g. "I am developing respect for other people"), social skills (8 items; e.g. "I am sensitive to the needs and feeling of others") and a positive identity (6 items; e.g. "I feel good about myself"). 
A four-point Likert scale ranging from not at all or rarely (1) to extremely or almost always (4) was offered to assess the items. Mean scores were calculated for each subscale, as well as the overall score for internal and external assets by adding the means in the respective dimensions (ranging from 4 to 16). Concerning the subscales of external assets, acceptable scores of reliability were detected for support $(\alpha=.79)$ and boundaries and expectations $(\alpha=.72)$, whereas low ones were observed for empowerment $(\alpha=$ $.69)$ and especially for constructive use of time $(\alpha=34)$. In the internal assets' dimensions, commitment to learning $(\alpha=.77)$, a positive identity $(\alpha=$ $.76)$ and positive values $(\alpha=.72)$ presented acceptable internal consisten$c y$, while social competence showed a low value $(\alpha=.68)$. Previous research by Scales (2011) established good cross-cultural validity in adolescents and youth, and good factorial and convergent validity.

Lifestyles. To measure the different types of behaviours that may characterise the lifestyle of young people, we used some indicators from the Positive Youth Development cross-national project (Wiium \& Dimitrova, 2019). These items assessed the level of physical activity ("I engage in physical activity, for at least 30 minutes, two or more times per week"), the consumption of fruit ("I eat at least one serving of fruit every day") and vegetables ("I eat at least one serving of vegetables every day"), alcohol use ("Have you consumed alcohol once or more in the last 30 days?"), drunkenness ("Have you been drunk once or more in the last 30 days?"), smoking ("Have you smoked a cigarette once or more in the last 30 days?"), substance inhalation ("Have you sniffed or inhaled substances to get high once or more in the last 12 months?", cannabis use ("Have you used marijuana once or more in the last 12 months?"), use of other illicit drugs ("Have you used other illicit drugs (e.g. cocaine, LSD, heroin, amphetamines etc.) once or more in the last 12 months?") and gambling ("Have you gambled with money once or more in the last 12 months?"). Dichotomic Yes/No response options were presented for each of these statements.

\section{Data collection procedure}

The present research uses Spanish data from the Positive Youth Development Cross-National project (Wiium \& Dimitrova, 2019). This international project is based on a sample of over 10,000 youth (aged 16-29) in Europe (Albania, Bulgaria, Greece, Italy, Kosovo, Macedonia, Norway, Portugal, Serbia, Slovenia, Spain, Turkey), Africa (Ghana, Kenya, South Africa), Asia (China), Latin America (Brazil, Mexico) and New Zealand. In Spain, the 
research followed a cross-sectional design with data being collected during April and May in 2017. The students anonymously completed a self-report measure, which required around 30 minutes, during normal class time in the presence of a previously trained research team member. This research was approved by the University of Huelva's ethics board. The ten high schools and universities contacted agreed to join in the research. All students agreed to participate and provided written informed consent, and parents' informed consent in the case of minors. The participants did not receive any reward for being involved in the study.

\section{Design of the data analyses}

Descriptive statistics were presented (i.e. mean and standard deviation) for the developmental assets and for the collective dimensions of internal and external assets. The frequency distribution was also examined for the behaviours reflecting lifestyles. We examined differences in developmental assets among participants who had reported various behaviours/lifestyles by performing Student t-tests. Cohen's d was shown for effect size. Means and standard deviation for developmental assets were presented for the dichotomic responses in each lifestyle behaviour. The statistical package JASP 0.14.1.0 was used.

\section{Results}

Table 1 presents descriptive statistics (i.e. mean and standard deviation) of developmental assets and the frequency distribution of lifestyles (i.e. the share answering "yes"). On the range of possible scores, the results indicated moderate scores for internal and external developmental assets. The mean score for internal assets was $11.98(S D=1.43)$, while $11.13(S D=1.58)$ was the mean for external assets, considering a range of possible scores from 4 to 16 . Thus, higher values were observed for the internal assets, especially social skills and commitment to learning. Further, in the external assets' dimensions, the highest score was found for empowerment, while the lowest one was detected for constructive use of time, which was also the dimension with the lowest internal consistency.

Regarding lifestyles, less than $60 \%$ of the sample reported having engaged in physical activity for at least 30 min two or more times per week, and having eaten at least one serving of vegetables or fruit every day. With regard to alcohol use, three-quarters of the sample had consumed alcohol once or more over the previous 30 days, and around $40 \%$ had been drunk 
once or more in the last month. Nearly $40 \%$ of the participants had smoked a cigarette once or more in the last month. Concerning illegal drugs, nearly one-quarter of the sample had used marijuana once or more in the last year, while around $4 \%$ had sniffed or inhaled substances or used other illicit drugs (e.g. cocaine, LSD, heroin, amphetamines etc.) once or more in the last year. Finally, $28 \%$ indicated that they had gambled with money once or more over the last year.

\section{Table 1: Descriptive statistics of developmental assets and frequency distribution of lifestyles.}

\begin{tabular}{lc}
\multicolumn{1}{c}{ Developmental assets } & M (SD) \\
Support & $2.94(.55)$ \\
\hline Empowerment & $3.15(.45)$ \\
\hline Expectancies and boundaries & $2.92(.43)$ \\
\hline Constructive use of time & $2.13(.61)$ \\
\hline Commitment to learning & $3.01(.52)$ \\
\hline Positive values & $2.97(.41)$ \\
\hline Social skills & $3.12(.44)$ \\
\hline Positive identity & $2.87(.55)$ \\
\hline Internal assets & $11.98(1.43)$ \\
\hline External assets & $11.13(1.58)$ \\
\hline Lifestyles & $\%$ Yes \\
\hline Physical activity & 58.3 \\
\hline Fruit & 58.9 \\
\hline Vegetables & 59.6 \\
\hline Alcohol & 75.9 \\
\hline Been drunk & 40.2 \\
\hline Smoking & 38.9 \\
\hline Betting & 28.0 \\
\hline Inhalation & 4.6 \\
\hline Marijuana & 24.8 \\
\hline & 3.8 \\
\hline
\end{tabular}

Table 2 shows differences in scores for developmental assets by the level of physical activity, and the consumption of fruit and vegetables. Participants with an active lifestyle (performing physical activity for at least 30 min two or more times per week) showed higher scores for the constructive use of time, a positive identity, positive values, and empowerment, as well as higher scores for overall internal and external assets. Concerning fruit and vegetables, those who indicated their daily consumption presented greater means in positive values and in the overall dimension of internal 
Table 2: T-tests of the mean scores for developmental assets by the level of physical activity, and the consumption of fruit and vegetables.

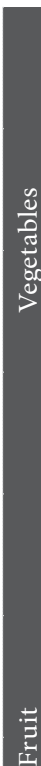

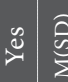

$\tau$

$\overline{3}$

$\stackrel{\circ}{\ddot{z}} \stackrel{\hat{n}}{z}$

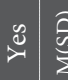

$\tau$

$\frac{\sum_{0}^{3}}{\frac{\pi}{2}}$

乙

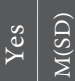

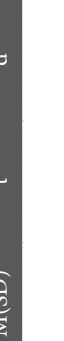

辛

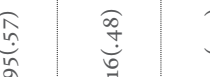

ते

๑.

7

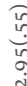

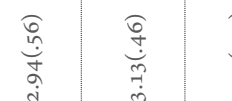

के

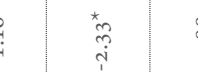

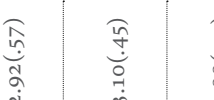

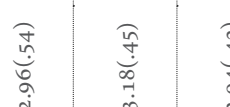

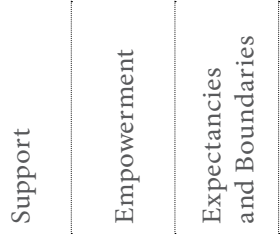

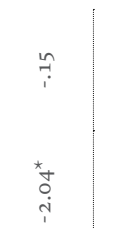

(3)

(

商

$\stackrel{\circ}{\circ}$

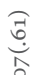

+

$\underset{\substack{0 \\ \text { i } \\ \text { i }}}{ }$

$\infty$

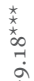

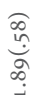

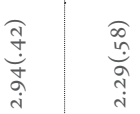

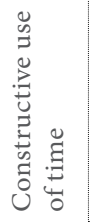

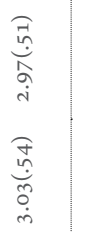

$$
7
$$

:

7

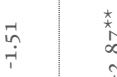

ia

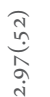

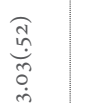

$\frac{\text { Fे }}{\stackrel{7}{\circ}}$

요

aे

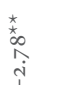

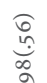

(

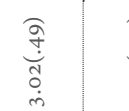

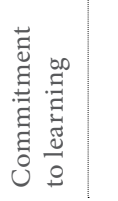

กุ

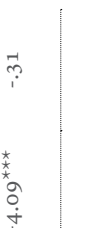

局

ปั

$\stackrel{i}{i} \quad \cdots \quad \infty$

3
$\frac{4}{4}$
$\pi$

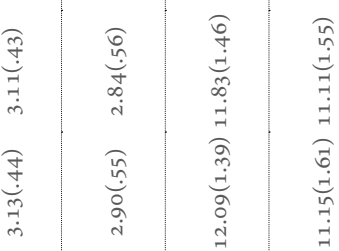

$\begin{array}{llll}1 & i & i\end{array}$

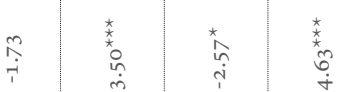

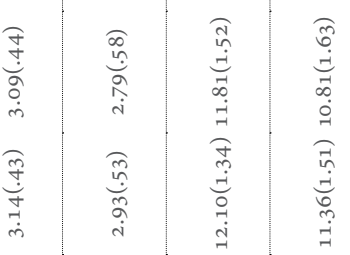

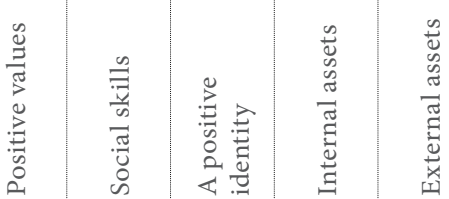


Table 3: T-tests of the mean scores for developmental assets by the consumption of alcohol and tobacco, and the practice of betting.

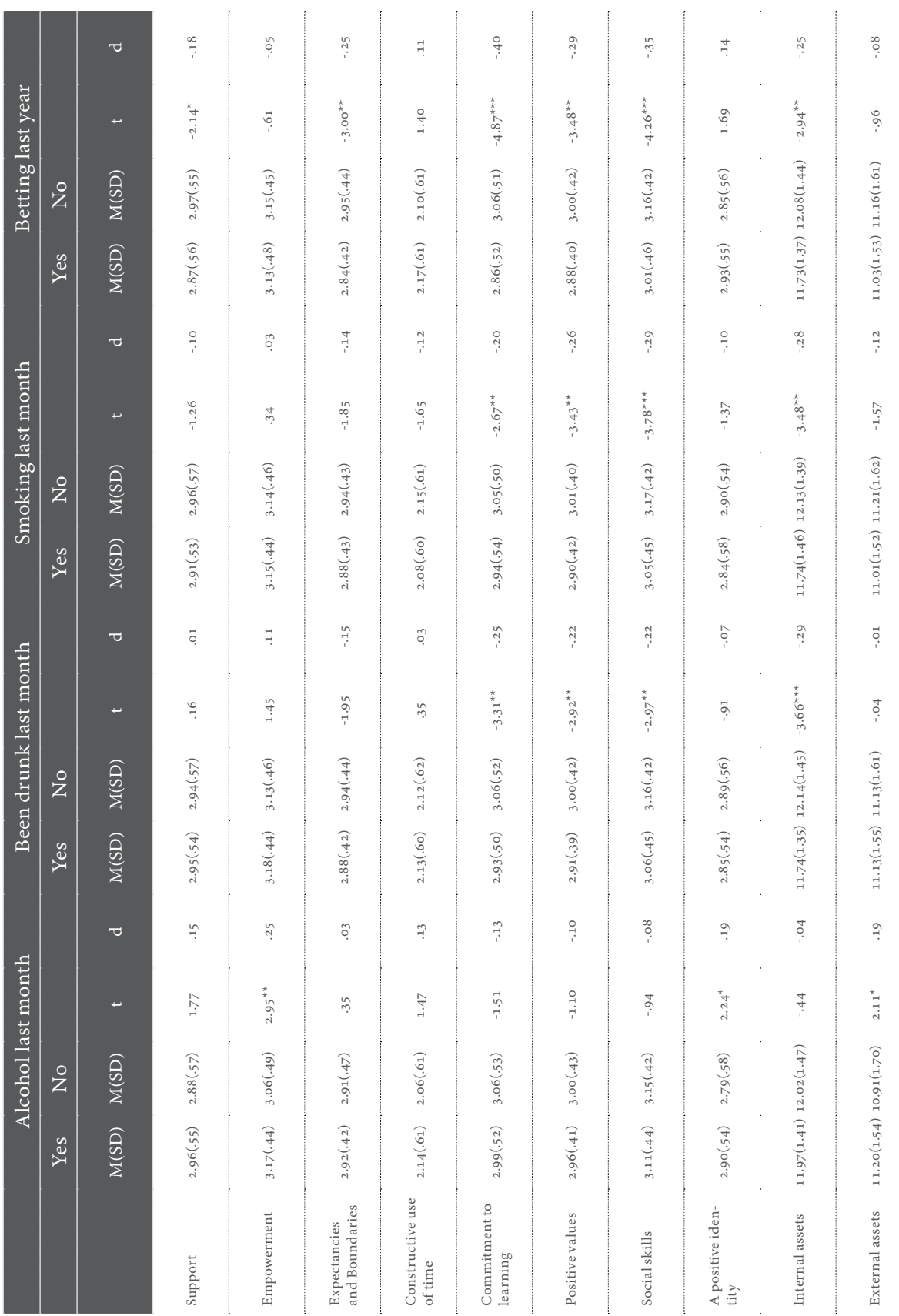


Table 4: T-tests of the mean scores for developmental assets by the consumption of illegal drugs.

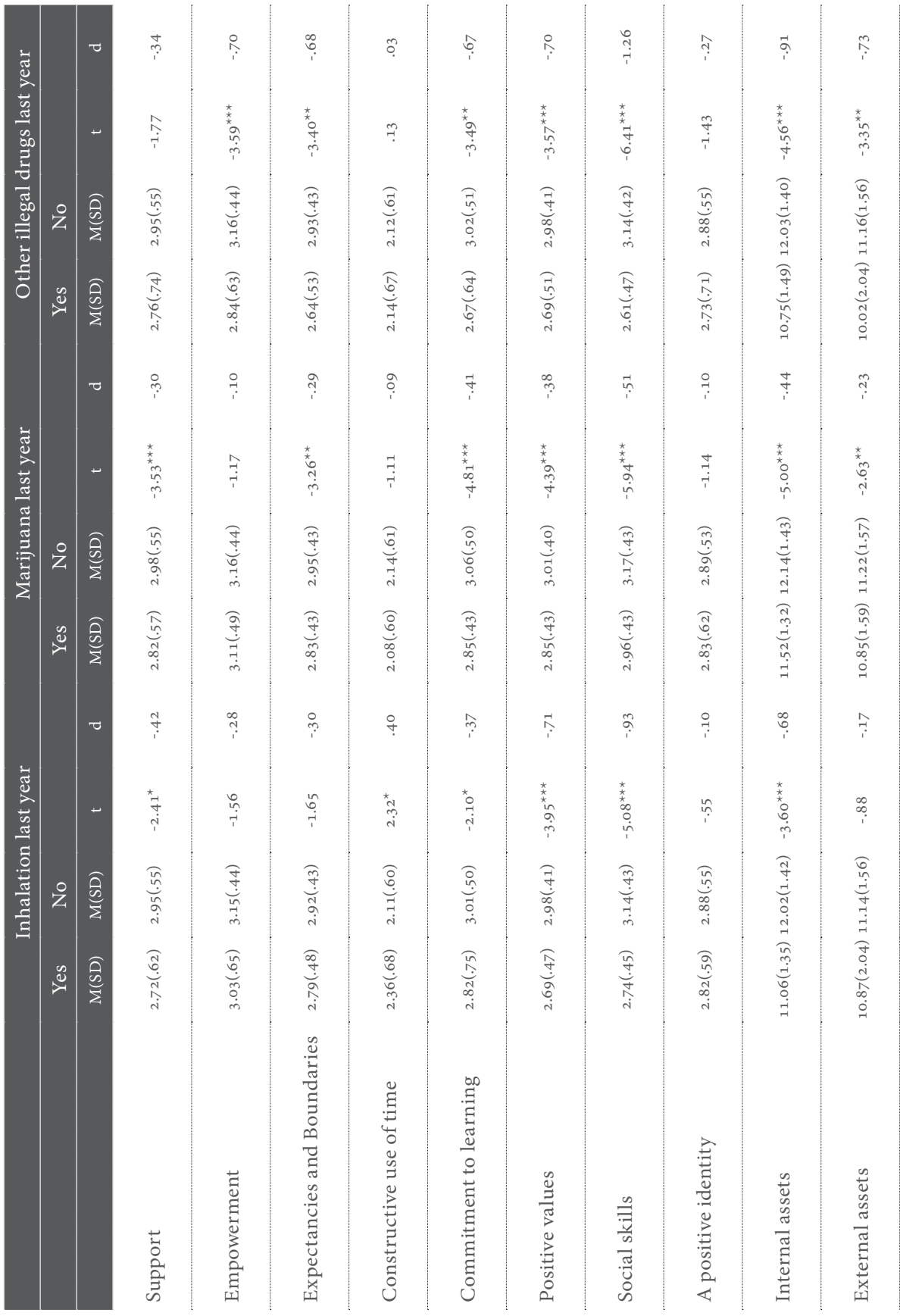


assets. Those who reported the daily consumption of vegetables showed more constructive use of time and more social skills.

Table 3 presents t-tests of the mean scores for developmental assets by the consumption of alcohol and tobacco, and the practice of betting. First, the results indicated that young people who drank alcohol once or more in the last month had more empowerment and a stronger positive identity, as well as more overall external assets. However, those who had been drunk once or more over the last month or smoked a cigarette once or more in that period indicated a lower commitment to learning, positive values, and social skills, and lower scores for overall internal assets. Betting was associated with lower scores for commitment to learning, social skills, positive values, boundaries and expectations, and social support. Participants who reported they had been betting also showed lower scores in the dimension of internal assets.

Finally, Table 4 presents the results of the t-tests of the mean scores for developmental assets by the consumption of illegal drugs. The consumption of marijuana or another illicit drug, and the inhalation of substances, over the last year, was linked to lower scores for social skills, positive values and commitment to learning, as well as a lower overall average for the internal assets' dimension. Specifically, the use of marijuana and inhalation were associated with less support, while the use of marijuana or another illicit drug was associated with fewer boundaries and expectations. Less empowerment was detected among those who had used another illicit drug. More constructive use of time was paradoxically indicated by those who had reported substance inhalation. Concerning the overall scores for external assets, a lower average was observed among participants who reported having used marijuana or another illicit drug.

\section{Discussion}

The aim of this study was to examine the associations between internal and external assets and lifestyles among young people; specifically, their physical activity, fruit and vegetable consumption, consumption of substances (alcohol, tobacco, marijuana, substance inhalation, others) and gambling. In line with our hypothesis, the greater presence of internal and external developmental assets was associated with a healthier lifestyle, with more health protective behaviours and less risk behaviours. In detail, an active lifestyle, involving the performing of physical activity for at least $30 \mathrm{~min}$ two or more times per week, was related to the more constructive use of 
time, a positive identity, positive values, and empowerment. Positive values were also positively associated with the daily consumption of fruit and vegetables. The daily consumption of vegetables was also related to more constructive use of time and more social skills. In addition, having been drunk or having smoked in the last month was associated with less commitment to learning, fewer positive values and fewer social skills. Use of marijuana over the last year was associated with less support and fewer boundaries and expectations. Finally, betting in the last year was related to lower scores for commitment to learning, social skills, positive values, boundaries and expectations, and social support. These results are in harmony with previous studies, such as those by Leffert et al. (1998) and Atkins et al. (2002) in the USA and Sahar et al. (2020) in Norway. Thus, as indicated by Oliva (2015), developmental assets constitute the basis for young people's healthy development. The current findings provide evidence of the association between developmental assets and a healthy lifestyle (health protective behaviours and no risk behaviours) and point to assets as resources that may promote health in individuals' transition to adulthood. More research is needed to better understand the mechanisms that explain these interrelations between developmental assets and the development of a healthy lifestyle, composed by particular health protective behaviours and the absence of risky behaviours. More internal and external assets may respectively facilitate the choice of protective behaviours and their availability in developmental contexts, thereby leading to greater attention to one's own and others' health and well-being as individuals develop.

Some limitations of these results must be noted. Like with any cross-sectional study, the conclusions are only based on associations between the variables, and no causal inference may be drawn, nor as concerns the direction of the relationship. Future research is needed to explore the prospective links between developmental assets, lifestyle and health. Moreover, greater research is called for to explore the mechanisms at work in these relationships as well as the different developmental profiles by demographics, for example, different patterns by gender. Other limitations may arise from the use of self-report measures, which present subjective and perceived information and should be complemented with objective measures of assets in the community. The subscale of constructive use of time showed low internal consistency, which may influence the results, and needs further psychometric research to develop a more solid measure for Spanish samples. Regarding the data analysis strategy, although the analyses conducted 
are appropriate for examining differences in developmental assets by lifestyles (assessed using dichotomic items), further examination would benefit from the use of multivariate regression-based analyses to study possible mediators and moderators, and from the design of a comprehensive structural equation model. Finally, other variables should be controlled, such as psychological adjustment and health conditions, personality traits or self-regulation. Future research could address the prospective relationships between developmental assets, lifestyles and physical/mental health by controlling for self-regulation, personality and demographics.

Despite these limitations, the results of this research suggest some implications for theory, policy and practice. Concerning the theoretical implications, health promotion among young people should integrate the construction of resilience with risk factors and the development of competencies and assets (Guerra \& Bradshaw, 2008). The design of intervention programmes for young people must integrate the promotion of assets to complement the classic view of adolescents and youth solely focused on risks and vulnerabilities. Regarding policy, local policies designed to prevent risk behaviours may be complemented with actions to strengthen assets on both internal and external levels to make them more efficient. Policies to promote health and well-being should follow an integrated and positive conception of youth by considering both strengths and contextual resources, and putting evidence-based interventions into practice. Some implications for professional practice also arise from this study. Curran and Wexler (2017) revised programmes to promote PYD from an educational context. Three categories of interventions were included, i.e. curriculum-based, leadership development and student-based mentorship programmes. Regarding curriculum-based approaches, programmes were focused on the development of social and emotional competencies. Taylor et al. (2017) performed a meta-analysis of social and emotional learning programmes to promote PYD, concluding that these interventions were effective for improving a healthy developmental trajectory. In Spain, the Happy Classrooms Programme is a good example of intervention in positive education that has proven its effectiveness in building adolescents' character strengths (Arguis et al. 2010). As regards programmes focused on leadership and mentoring, one example is Portugal's Dream teens project aimed at promoting social participation and PYD (Branquinho et al., 2020). The authors conducted a participatory action-research programme which presented positive effects on personal development, feelings of social 
support, and relationships. In Spain, the Healthy Universities Network was recently established to foster health and well-being within Spanish universities (REUS, 2018), while the Spanish Institute for Youth (2018) has started actions to enhance social participation and empowerment in youth by promoting international cooperation, youth associationism, youth creativity, the training of information agents, and the exchange of experiences.

In conclusion, the study presents evidence of positive relationships in Spain between developmental assets and healthy lifestyles, and reinforces the results obtained in other countries. Most research to date on developmental assets and their associations with health and well-being has been conducted with samples from North America and the current research results underline the importance of assets for healthy development also in a Spanish sample of youth. This study examined the associations between individual internal and external assets with several lifestyle behaviours, i.e. practice of physical activity, the consumption of fruit and vegetables, alcohol use, having been drunk, smoking, substance inhalation, cannabis use, use of other illicit drugs and betting. The results revealed different profiles of both internal and external assets that were associated with more physical activity and greater consumption of fruit and vegetables, as well as less risk behaviours (substance use and gambling). Thus, this research suggests the need to design programmes to foster developmental assets and to promote healthy lifestyles in order to support a healthy transition to adulthood.

\section{References}

Arguis, R., Bolsas, A., Hernandez, S., \& Salvador, M. (2010). The "Happy Classrooms" Programme. Positive Psychology applied to education. http:// educaposit.blogspot.com.es/p/free-programme-download.html

Atkins, L. A., Oman, R. F., Vesely, S. K., Aspy, C. B., \& McLeroy, K. (2002). Adolescent tobacco use: the protective effects of developmental assets. American Journal of Health Promotion, 16(4), 198-205. https://doi. org/10.4278/o890-1171-16.4.198

Benson, P. L., Scales, P. C., Hamilton, S. F., \& Sesma, A. (2006). Positive youth development: Theory, research, and applications. In R. M. Lerner (Ed.). Theoretical models of human development. Volume 1 of Handbook of Child Psychology (pp. 894-941). Wiley.

Benson, P. L., Scales, P. C., \& Syvertsen, A. K. (2011). The contribution of the developmental assets framework to positive youth developmental theory 
and practice. Advances in Child Development and Behavior, 41, 197-230. https://doi.org/10.1016/B978-0-12-386492-5.00008-7

Bleck, J., \& DeBate, R. (2016). Long-term association between developmental assets and health behaviors: an exploratory study. Health Education of Behavior, 43(5), 543-551. https://doi.org/10.1177/1090198115606915

Branquinho, C., Gomez-Baya, D., \& de Matos, M. G. (2020). Dream Teens Project in the Promotion of Social Participation and Positive Youth Development of Portuguese Youth. EREBEA. Revista de Humanidades $y$ Ciencias Sociales, 10, 69-84. http://www.uhu.es/publicaciones/ojs/index. php/erebea/article/view/4955

Catalano, R. F., Hawkins, J. D., Berglund, M. L., Pollard, J. A., \& Arthur, M. W. (2002). Prevention science and positive youth development: Competitive or cooperative frameworks?. Journal of Adolescent Health, 31(6), 230-239. https://doi.org/10.1016/s1054-139x(02)00496-2

Curran, T., \& Wexler, L. (2017). School-based positive youth development: A systematic review of the literature. Journal of School Health, 87(1), 71-80. https://doi.org/10.1111/josh.12467

EDADES (2019). Alcohol, tabaco y drogas ilegales en España [Alcohol, tobacco and ilegal drugs in Spain]. https://pnsd.sanidad.gob.es/profesionales/sistemasInformacion/sistemaInformacion/pdf/2019_Estadisticas_ EDADES.pdf

Filbert, K. M., \& Flynn, R. J. (2010). Developmental and cultural assets and resilient outcomes in First Nations young people in care: An initial test of an explanatory model. Children and Youth Services Review, 32(4), 560-564. https://doi.org/10.1016/j.childyouth.2009.12.002

French, S. A., Leffert, N., Story, M., Neumark-Sztainer, D., Hannan, P., \& Benson, P. L. (2001). Adolescent binge/purge and weight loss behaviors: Associations with developmental assets. Journal of Adolescent Health, 28(3), 211-221. https://doi.org/10.1016/S1054-139X(oo)oo166-X

Fulkerson, J. A., Story, M., Mellin, A., Leffert, N., Neumark-Sztainer, D., \& French, S. A. (2006). Family dinner meal frequency and adolescent development: Relationships with developmental assets and high-risk behaviors. Journal of Adolescent Health, 39(3), 337-345. https://doi.org/10.1016/j. jadohealth.2005.12.026

Galinsky, A. M., \& Sonenstein, F. L. (2011). The association between developmental assets and sexual enjoyment among emerging adults. Journal of Adolescent Health, 48(6), 610-615. 
Geldhof, G. J., Bowers, E. P., Boyd, M. J., Mueller, M. K., Napolitano, C. M., Schmid, K. L., Lerner, J. V., \& Lerner, R. M. (2014). The creation and validation of short and very short measures of PYD. Journal of Research on Adolescence, 24(1), 163-176. https://doi.org/10.1111/jora.12039

Gomez-Baya, D., Santos, T., \& Gaspar de Matos, M. (2021). Developmental assets and positive youth development: an examination of gender differences in Spain. Applied Developmental Science. Advance online publication. https://doi.org/10.1080/10888691.2021.1906676

Guerra, N. G., \& Bradshaw, C. P. (2008). Linking the prevention of problem behaviors and positive youth development: Core competencies for positive youth development and risk prevention. New Directions for Child and Adolescent Development, 122, 1-17. https://doi.org/10.1002/cd.225

INJUVE (2019). Juventud y juegos de azar. Una visión general del juego en los jóvenes [Youth and gambling. An overview]. http://www.injuve.es/sites/ default/files/adjuntos/2019/o6/juventud_y_juegos_de_azar.pdf

Kia-Keating, M., Dowdy, E., Morgan, M. L., \& Noam, G. G. (2011). Protecting and promoting: An integrative conceptual model for healthy development of adolescents. Journal of Adolescent Health, 48(3), 220-228. https:// doi.org/10.1016/j.jadohealth.2010.08.006

Kozina, A., \& Pivec, T. (2020). Contextual and Individual Predictors of Bullying and Victimization in Slovenia: Positive Youth Development Perspective. EREBEA. Revista de Humanidades y Ciencias Sociales, 10, 85-110. http:// www.uhu.es/publicaciones/ojs/index.php/erebea/article/view/4961

Larson, R. W. (2000). Toward a psychology of positive youth development. American Psychologist, 55(1), 170-183. https://doi. org/10.1037/0003-066X.55.1.170

Leffert, N., Benson, P. L., Scales, P. C., Sharma, A. R., Drake, D. R., \& Blyth, D. A. (1998). Developmental assets: Measurement and prediction of risk behaviors among adolescents. Applied Developmental Science, 2(4), 209230. https://doi.org/10.1207/s1532480xadso204_4

Lerner, R. M., Almerigi, J. B., Theokas, C., \& Lerner, J. V. (2005). Positive youth development a view of the issues. The Journal of Early Adolescence, 25(1), 10-16. https://doi.org/10.1177/0272431604273211

Lerner, R. M., Dowling, E. M., \& Anderson, P. M. (2003). Positive youth development: Thriving as the basis of personhood and civil society. Applied Developmental Science, 7(3), 172-180. https://doi.org/10.1207/ S1532480XADSo703_8 
Lerner, R. M., Lerner, J. V., Bowers, E., \& Geldhof, G. J. (2015). Positive youth development and relational developmental systems. In W. F. Overton \& P. C. Molenaar (Eds.), Theory and method. Volume 1 of the Handbook of child psychology and developmental science (pp. 607-651). Wiley.

Lippman, L. H., Moore, K. A., \& McIntosh, H. (2011). Positive indicators of child well-being: A conceptual framework, measures, and methodological issues. Applied Research in Quality of Life, 6(4), 425-449. https://doi. org/10.1007/s11482-011-9138-6

INE (2017). Encuesta Nacional de Salud: 2017 [National Health Survey: 2017]. https://www.ine.es/dynt3/inebase/es/index.htm?type=pcaxis\&path=/t15/ p419/a2017/po3/\&file $=$ pcaxis

Oliva, A. (2015). Los activos para la promoción del desarrollo positivo adolescente [Assets for promoting positive adolescent development]. Revista Metamorfosis: Revista del Centro Reina Sofía sobre Adolescenciay Juventud, (3), 32-47. https://dialnet.unirioja.es/servlet/articulo?codigo $=6163218$

REUS (2018). Las universidades como centros promotores de salud [Universities as centers for health promotion]. https://www.unisaludables.es/media/ docs/CONSE/DOCUMENTO_CONSENSO_RECTORES_3.docx

Sahar, I., Rossland, M. F., \& Wiium, N. (2020). Risk Behaviors among Young People: The Role of Developmental Assets. EREBEA. Revista de Humanidades y Ciencias Sociales, 10, 31-52. http://www.uhu.es/publicaciones/ojs/index.php/erebea/article/view/4959

Scales, P. C. (1999). Reducing risks and building developmental assets: Essential actions for promoting adolescent health. Journal of School Health, 69(3), 113-119. https://doi.org/10.1111/j.1746-1561.1999.tbo7219.x

Scales, P. C. (2011). Youth developmental assets in global perspective: Results from international adaptations of the Developmental Assets Profile. Child Indicators Research , 4(4), 619-645. https://doi.org/10.1007/s12187-011-9112-8

Scales, P. C., Benson, P. L., Leffert, N., \& Blyth, D. A. (200o). Contribution of developmental assets to the prediction of thriving among adolescents. Applied Developmental Science, 4(1), 27-46. https://doi.org/10.1207/ S1532480XADSo401_3

Schwartz, S. E., Chan, C. S., Rhodes, J. E., \& Scales, P. C. (2013). Community developmental assets and positive youth development: The role of natural mentors. Research in Human Development, 10(2), 141-162. http://doi.org/1 o.1080/15427609.2013.786553 
Soares, A. S., Pais-Ribeiro, J. L., \& Silva, I. (2019). Developmental assets predictors of life satisfaction in adolescents. Frontiers in Psychology, 10, 236-247. http://dx.doi.org/10.3389/fpsyg.2019.00236

Spanish Institute for Youth (2018). Guía de servicios del INJUVE [Services guide of the Spanish Institute for Youth]. http://www.injuve.es/conocenos/ que-hacemos

Taylor, R. D., Oberle, E., Durlak, J. A., \& Weissberg, R. P. (2017). Promoting positive youth development through school-based social and emotional learning interventions: A meta-analysis of follow-up effects. Child Development, 88(4), 1156-1171. http://dx.doi.org/10.1111/cdev.12864

Theokas, C., Almerigi, J. B., Lerner, R. M., Dowling, E. M., Benson, P. L., Scales, P. C., \& von Eye, A. (2005). Conceptualizing and modeling individual and ecological asset components of thriving in early adolescence. The Journal of Early Adolescence, 25(1), 113-143. https://doi.org/10.1177/0272431604272460

Valois, R. F., Zullig, K. J., Huebner, E. S., \& Drane, J. W. (2009). Youth developmental assets and perceived life satisfaction: Is there a relationship?. Applied Research in Quality of Life, 4(4), 315-331. https://doi.org/10.1007/ s11482-009-9083-9

Wiium, N., \& Dimitrova, R. (2019). Positive youth development across cultures: Introduction to the special issue. Child \& Youth Care Forum, 48, 147-153. https://doi.org/10.1007/s10566-019-09488-7 